Génét. Sél. Evol., 1988, 20 (4), 409-416

\title{
Search for age-dependent as compared to mutagen-induced mutations on the $X$-chromosome affecting viability in Drosophila melanogaster males
}

\author{
T. BJÖRKLUND, G. ENGSTRÖM, Trudy McKAY ${ }^{*}$ and L.E. LILJEDAHL \\ Swedish University of Agricultural Sciences, Department of Animal Breeding and Genetics, \\ Box 7023, 75007 Uppsala, Sweden \\ * Institute of Animal Genetics, King's Buildings, West Mains Road, \\ Edinburgh EH9 $3 J N$, United Kingdom
}

\begin{abstract}
Summary
The effect of ageing on the possible accumulation of deleterious genetic changes compared to ethyl methane sulfonate (EMS) induced mutations on the X-chromosome in gametes was investigated in a laboratory population of Drosophila melanogaster males. To detect X-linked mutations affecting viability, differences in sex ratio (number of male offspring/number of female offspring) were measured in the progeny of these males taken at three different ages, or after EMS exposure, and mated to attached-X females. There were no significant differences in sex ratio for the three age periods but a strong significant difference in sex ratio after EMS exposure was obtained. This indicates that no age-dependent accumulation of mutations takes place in the germ cells.
\end{abstract}

Key words : ageing, mutagen (ethyl methane sulfonate) exposure, mutations, $X$-chromosome, Drosophila melanogaster.

\section{Résumé}

Recherche sur le chromosome $X$ de mutations dépendant de l'âge et affectant la viabilité chez les mâles Drosophila melanogaster : comparaison avec des mutations induites par mutagenèse

L'effet du vieillissement sur l'accumulation possible de changements génétiques sur le chromosome X de Drosophila melanogaster a été comparé à l'effet de l'éthyl-méthane-sulfonate (EMS) chez des mâles d'une population de laboratoire. Nous avons mesuré le sex ratio (nombre de descendants mâles/nombre de descendants femelles) dans la descendance de ces mâles pris à trois âges différents ou traités à l'EMS, et croisés à des femelles à $\mathrm{X}$-attachés. Le sex ratio dans ce type de croisement permet de mesurer les fréquences de mutations létales portées par le chromosome $X$. Aucune différence de sex ratio n'a été trouvée chez les mâles d'âges différents ; en revanche, une différence hautement significative apparaît après exposition à l'EMS. Ceci indique qu'il n'existe aucune accumulation de mutations létales au cours du vieillissement dans les gamètes mâles.

Mots clés : vieillissement, exposition à un mutagène (éthyl-méthane-sulfonate), mutations, chromosome $X$, Drosophila melanogaster. 


\section{Introduction}

Many authors (Szilard, 1959 ; Failla, 1960 ; Strehler, 1962 ; MedvedeV, 1964 ; AleXANDER, 1967) claim that changes in the genome take place in ageing cells. These age-dependent changes have been observed at different levels of DNA organization, from alteration in DNA sequences to chromosomal rearrangements : for a review see Gensler \& Bernstein (1981) and Macieira-Coelho (1984). There is also evidence available on increased mutation rate at specific loci in the later part of the life span of fibroblast cultures (BEARDMORE, 1976).

Physiological data further support the view that DNA is a primary target for and accumulates various forms of genetic damage, which arise partly as a result of the interaction of free radicals and electrophilic molecules within cellular DNA. The ability of an organism to maintain the stability of its genome depends upon the different systems that protect DNA from damaging agents or remove damaged portions of DNA, and to what extent damaged regions of the genome are expressed (HART \& MoDAK, 1980). Different repair mechanisms exist according to the nature of the genetic damage. Investigations made on the relation between DNA repair and ageing have shown contradictory results. Thus, KEMPF et al. (1984) and NiEDERMÜLLER et al. (1985) have found an age-dependent decline in DNA repair capacity, while others (for example Goldstein, 1971 ; Painter et al., 1973) have found no such decline.

MARINKović et al. (1973, 1975) presented experimental support that ageing of Drosophila melanogaster results in an increase in viability genetic load, which was expressed in second-chromosome homozygotes but not in heterozygous combinations of the same chromosomes. In another study, showing similar results, ANDJELKović et al. (1979) attempted to determine whether or not age-related changes in viability and longevity genetic loads in the second chromosome are inherited, i.e., are transmittable through young progenies of old $+/ C y L^{2}$ parental individuals. The results showed that the longevity genetic load was, according to the authors, heritable and probably due to accumulated recessive mutations in the gametes of aged parents.

LANSING (1954) using the rotifer Philodina citrina showed that the mean life span of offspring decreased successively in each generation in lines derived from middle-aged mothers. Rapid extinction occurred in the line maintained by senile mothers. In spite of an extensive search for such "Lansing " effects in Drosophila (ComforT, 1953; O'Brian, 1961 ; Wattiaux, 1968) and other organisms (Callahan, 1962 ; Flemings \& LuDWIG, 1964) no such clear-cut effects have since been observed in any species.

The object of this study is to explore whether mutations on the X-chromosome are accumulating as a result of the process of ageing compared with artificial induction by the chemical mutagen ethyl methane sulfonate (EMS) in Drosophila melanogaster.

\section{Material and methods}

The population of Drosophila melanogaster used in this experiment was a cross between four different equally contributing strains. The four-way strain was allowed to 
attain linkage equilibrium through more than 20 generations of random mating. From the four-way strain, 1500 males, all hatched within three days, were chosen at random.

All males were kept in vials with 10 males per vial, containing $3 \mathrm{~cm}$ standard medium (10 g agar, $60 \mathrm{~g}$ syrup, $50 \mathrm{~g}$ bakers yeast, $40 \mathrm{~g}$ powdered mashed potatoes, $0.75 \mathrm{~g}$ ascorbic acid and $2 \mathrm{ml}$ propionic acid per liter of water). The flies were kept in the same incubator at $25^{\circ} \mathrm{C}$ and $45 \%$ relative humidity. A lighting scheme comprised of 16 hours light and 8 hours dark was used. All handling was performed at room temperature using $\mathrm{CO}_{2}$ anaesthesia.

The males were transferred to new vials twice a week throughout the experimental period. At the ages of 5,21 and 35 days (age periods 1,2 and 3 respectively), about 300 sires were randomly chosen and each sire mated with 3 virgin " attached-X females. These age periods were chosen to obtain sire survival rates of approximately 100,85 and $35 \%$. The $\hat{X X}$-females were no older than 5 days when mated with the males at the different age periods.

The sire groups consisting of one male and three $\hat{X X}$-females were kept in separate vials for six consecutive egglaying days during each of the three age periods. After 10 and 14 days from the first day of egglaying in each age period, the number of male and female offspring from each sire group were recorded. Male and female offspring from the two recordings in each sire group were combined and used as a single observation of total number of male and female offspring. In addition the sex ratio in each sire group was calculated as the total number of male offspring divided by the total number of female offspring.

Sex chromosomes of $\hat{X X}$-females consist of two X-chromosomes and one $\mathrm{Y}$ chromosome. The two $\mathrm{X}$-chromosomes are attached to each other and segregate together during meiosis. Due to the genetic constitution of the $\hat{X} X$-female, male offspring of these females get their X-chromosome from the sire (see fig. 1). Thus, the proportion of male-to-female offspring from the cross between a wild-type male and an $\mathrm{XX}$-female reflects the genetic load in the sire X-chromosome.

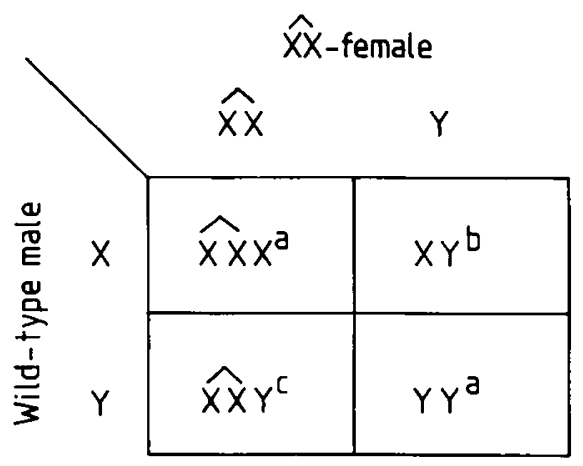

FIG. 1

Distribution of sex chromosomes in parental gametes and the resulting constitution of sex chromosomes in embryos ( $a$ : lethal combination of sex chromosomes, $b:$ viable wild-type male embryo, $c$ : viable $X X$-female embryo). 
Another random sample of 100 males was taken from the same base population as described above, all males hatched within one day. Five days after eclosion each male was subjected to EMS treatment for 24 hours according to the method described by LEWIS \& BACHER (1968) and were then immediately mated with three XX females. The same traits were recorded in the manner described above and the sex ratio was calculated for each sire group.

A phenotypic analysis was made on the following traits : number of male offspring, number of female offspring, total number of offspring, sex ratio and percentage of sterile sires. Sire sterility was calculated as the percentage of sires with no offspring from the total number of sires $(301,300$ and 327$)$ in each age period.

The single restriction imposed on the data (except for calculating sire sterility) was that only sire groups having more than 15 offspring were included in the analysis. As a result of this restriction $1,4,13$ and 0 observations (sire groups) were excluded from age periods 1, 2, 3 and EMS treatment respectively. The means and standard deviations of the traits were calculated for the different age periods and for the EMS treatment.

\section{Results}

The results are presented in table 1. The mean values for number of male offspring, number of female offspring and total number of offspring decreased throughout the three age periods, with highly significant differences between them $(P \leqslant 0.001)$. For the trait sex ratio the value remained constant over the three age periods.

TABLE 1

Descriptive statistics for different age period and EMS (ethyl methane sulfonate) treatment

\begin{tabular}{|c|c|c|c|c|c|}
\hline & & \multicolumn{3}{|c|}{ Age period } & \multirow{2}{*}{$\begin{array}{c}\text { EMS } \\
\text { treatmen }\end{array}$} \\
\hline & & 1 & 2 & 3 & \\
\hline \multirow{2}{*}{\multicolumn{2}{|c|}{$\begin{array}{l}\text { Number of sires } \\
\text { Sire sterility }(\%)\end{array}$}} & 295 & 280 & 244 & 97 \\
\hline & & 1,66 & 5,33 & 21,41 & 3,00 \\
\hline \multirow[t]{2}{*}{ Number of male offspring } & $\bar{X}$ & 46,71 & 39,22 & 33,70 & 13,59 \\
\hline & S.D. & 11,36 & 9,38 & 10,14 & 5,02 \\
\hline \multirow[t]{2}{*}{ Number of female offspring } & $\bar{X}$ & 28,67 & 24,15 & 20,77 & 25,75 \\
\hline & S.D. & 7,67 & 6,61 & 6,16 & 7,43 \\
\hline \multirow[t]{2}{*}{ Total of number of offspring } & $\hat{X}$ & 75,38 & 63,36 & 54,48 & 39,34 \\
\hline & S.D. & 16,51 & 13,70 & 13,98 & 10,45 \\
\hline \multirow[t]{2}{*}{ Sex ratio ${ }^{\text {(a) }}$} & $\dot{X}$ & 1,71 & 1,71 & 1,73 & 0,56 \\
\hline & S.D. & 0,52 & 0,52 & 0,78 & 0,24 \\
\hline
\end{tabular}

$\bar{X}=$ mean ; S.D. $=$ standard deviation.

(a) Sex ratio calculated as number of male offspring on female offspring. 
The mean values for number of male offspring from EMS-treated sires was approximately $29 \%, 35 \%$ and $40 \%$ of the mean from untreated (ageing) sires in age period 1, 2 and 3 respectively. Number of female offspring from EMS treated sires compared to number of female offspring from sires in age period 1 was not greatly affected, but the difference was significant $(P \leqslant 0.01)$. Thus, the differences in total number of offspring and sex ratio between EMS treated and untreated (ageing) sires were highly significant $(P \leqslant 0.001)$. The percentage of sterile sires increased throughout the three age periods and was most pronounced in the last age period, whereas the percentage of sterile sires after the EMS treatment was approximately twice that of the sires in age period 1.

\section{Discussion}

This study deals with the effect of ageing on the possible accumulation of deleterious mutations on the X-chromosome in gametes of male Drosophila melanogaster. The effects of $\mathrm{X}$-linked recessive deleterious mutations affecting viability will be perceived as a reduction in the proportion of male progeny from $\hat{\mathrm{X} X}$-females, as these males carry the paternal X-chromosome. Various forms of genetic damage and mutations may accumulate in ageing cells. To compare any effect of ageing with that of a known mutagen, a sample of males was treated with EMS, and X-chromosomes exposed to EMS were assessed in the same manner as those from the ageing males. It must be stressed that the effect of mutagen exposure is not considered to act in the same way on the organism as normal ageing. It can not, however, be excluded that age-dependent genetic changes, to a certain extent, are of the same kind as EMSinduced damages.

Since the sex ratio did not change with age of the male parent, it is assumed that no or a very small and undetectable accumulation of deleterious mutations occur in the $\mathrm{X}$-chromosome of the germ cells. However, the result is inconsistent with the findings of ANDJELKović et al. (1979) indicating that such an age-related accumulation of harmful mutations does occur.

The observed decline in both male and female offspring with increased paternal age and the dramatic increase in sterility, may reflect the general decline in vitality and increased accumulation of DNA damage in the various stages of spermatogenesis of ageing males. Accumulation of DNA damage with advancing age in the early stage of spermatogenesis leads to increased sterility. If DNA damage occurs in spermatids/ sperms both number of male and female progeny should be reduced whether the damage is present in autosomes or in sex chromosomes, due to the lethal effects through the blockage of DNA replication produced by DNA damage. The observed decline in both number of male and female progeny and increase in sterility with age is consistent with an accumulation of genetic damage in germ line with age.

Males exposed to EMS showed a drastically reduced number of male offspring, a slight but significant reduction in number of female offspring, and a small effect on sterility. The high frequency of harmful recessive mutations implied by the drastically reduced number of male offspring did not greatly affect the number of female offspring nor sire sterility. This further emphasizes the importance of interpreting the expected effects of mutations and DNA damage separately. 
The discrepancy between our results and those obtained by ANDJELKović et al. (1979) is difficult to interpret. In the latter investigation the authors examined agerelated changes in viability and longevity due to recessive mutations in homozygous second chromosomes. Both female and male parents and/or grandparents were old and $+/ C y L^{2}$ individuals. The present study deals with age-related recessive mutations in the $\mathrm{X}$-chromosome of old wild-type males. Whether differences in the $D$. melanogaster stocks used and/or in the experimental design account for the discrepancy is questionable. However, a significant decline in the number of male as well as female offspring with advancing age of the sire was obtained in both investigations. If this result is interpreted as being due to an age-related accumulation of DNA damage and/or a decline in vitality, there is no disagreement in this respect.

In order to examine the importance of the protective mechanisms of DNA repair and its correlation with ageing more thoroughly, this study will be continued by a project for selection of resistance to a mutagen in positive and negative directions.

Received May 6, 1987. Accepted January 14, 1988.

\section{References}

Alexander P., 1967. The role of DNA lesions in processes leading to ageing in mice. Symp. Soc. Exp. Biol., 21, 29-50.

Andjelković M., Marinković P., Tucić N., Tocić M., 1979. Age-affected changes in viability and longevity loads of Drosophila melanogaster. Am. Nat., 114, 915-939.

Beardmore J.A., 1976. Genetics and ageing. Eugen. Soc. Bull., 8, 39-42.

Callahan R.F., 1962. Effects of parental age in the life cycle of the house fly Musca domestica. J. N.Y. Entomol. Soc., 70, 150.

Comfort A., 1953. Absence of a Lansing effect in Drosophila subobscura. Nature, 172, 83-83.

Failla G., 1960. The ageing process and somatic mutation. In : Strehler B.L. (ed.), The biology of ageing, 170-175, American Institute of Biological Sciences, Washington D.C.

Flemings M.B., Ludwig D., 1964. Effects of temperature and parental age on the life cycle of the body louse, Pediculus humanus humanus. Ann. Entomol. Soc. Amer., 57, 560-563.

Gensler H.L., Bernstein H., 1981. DNA damages as the primary cause of ageing. Quart. Rev. Biol., 56, 279-303.

GoldsteIN S., 1971. The role of DNA repair in ageing of cultured fibroblast from xeroderma pigmentation and normals. Proc. Soc. Exp. Biol. Med., 137, 730.

Hart R.W., Modak S.P., 1980. Ageing and changes in genetic information. Adv. Exp. Med. Biol., 129, 123-137.

KempF C., Schmitr M., Panse J.-M., KempF J., 1984. Correlation of DNA repair synthesis with ageing in mice, evidence by quantitative autoradiography. Mech. Ageing Dev., 26, 183-194.

Lansing A.I., 1954. A non-genetic factor in the longevity of rotifers. Ann. N.Y. Acad. Sci., 57, 455-464.

Lewis E.B., Bacher F., 1968. Method of feeding ethyl methane sulfonate (EMS) to Drosophila males. Dros. Inf. Serv., 43, 193.

Macieira-Coelno A., 1984. Genome reorganization during cellular senescence. Mech. Ageing Dev., 27, 257-262.

Marinković P., Tucić N., Andjelković M., 1973. Age associated changes in viability genetic loads of Drosophila melanogaster. Exp. Gerontol., 8, 199. 
Marinković P., Tucić N., Andjelković M., 1975. The effect of streptomycin on age-associated viability genetic loads in Drosophila melanogaster. Acta Biol., 7/8, 339-343.

Medvedev Z.A., 1964. The nuclei acids in development and ageing. Adv. Gerontol. Res., 1, 181206.

Nidermüller H., Hotecher G., Skalicky M., 1985. Changes of DNA repair mechanisms during the ageing of the rat. Mech. Ageing Dev., 29, 221-238.

O'Brian D.M., 1961. Effects of parental age on the life cycle of Drosophila melanogaster. Ann. Entomol. Soc. America, 54, 412-416.

Painter R.B., Clarkson J.M., Young B.R., 1973. Ultraviolet-induced repair replication of ageing diploid human cells (UWI-38). Radiat. Res., 56, 560.

StreHLER B.L., 1962. Further studies on the thermal-induced ageing of Drosophila melanogaster. J. Gerontol., 17, 347-353.

Szilard L., 1959. On the nature of ageing process. Proc. Natl. Acad. Sci., 45, 1145-1147.

Wattiaux J.M., 1968. Parental age effects in Drosophila pseudoobscura. Exp. Gerontol., 3, 55-61. 